\title{
Pengaruh Model Pembelajaran Kooperatif Tipe Kancing Gemerincing dan Motivasi Belajar terhadap Hasil Belajar Mahasiswa pada Mata Kuliah Ekonomi Politik di Program Studi Pendidikan Ekonomi Fakultas Keguruan dan Ilmu Pendidikan Universitas Batanghari Jambi
}

\author{
Diliza Afrila* \\ Fakultas Keguruan dan Ilmu Pendidikan Universitas Batanghari Jambi \\ *Correspondence email: dilizaafrila@unbari.ac.id
}

\begin{abstract}
This study aims to determine (1) Student learning outcomes in the Political Economy course taught using cooperative learning model type Kancing Gemerincing are higher than students taught using conventional learning models in the Economic Education Study Program, (2) Student learning outcomes in the Political Economy course who has high learning motivation which is taught by using the cooperative learning model type Kancing Gemerincing is higher than students who have high learning motivation who are taught using conventional learning models in the Economic Education Study Program, (3) Student learning outcomes in the Political Economy courses who have low learning motivation who are taught using the cooperative learning model type Kancing Gemerincing are higher than students who have low learning motivation who are taught using conventional learning models in the Education Study Program Economics, and (4) the interaction between cooperative learning model type Kancing Gemerincing and learning motivation towards student learning outcomes in the Political Economy course in the Economic Education Study Program. This type of research is a quasi experiment. The study population was 27 students of the Economic Education Study Program Semester VI / A1 and VI / A2 Academic Year 2019/2020. The sampling technique was purposive sampling (purposive sampling). The results showed that (1) Student learning outcomes in the Political Economy course taught by using the cooperative learning model type Kancing Gemerincing were higher than those taught using conventional learning models. This is indicated by the $t$ value of 2.159 and the probability value of 0.041 . So that the probability value of 0.041 $<0.05$ then $\mathrm{H}_{0}$ is rejected, (2) Student learning outcomes in the Political Economy course who have high learning motivation who are taught using the cooperative learning model type Kancing Gemerincing are higher than students who have high learning motivation being taught with conventional learning models. This is indicated by the $t$ value of 7.260 and the probability value of 0.001 . Thus, the probability value of $0.001<0.05$ then $H_{0}$ is rejected, (3) The learning outcomes of students in the Political Economy course who have low learning motivation who are taught using cooperative learning model type Kancing Gemerincing are higher than students who have low learning motivation which taught by conventional learning models. This is indicated by the $t$ value of 1.532 and the probability value of 0.006 . Thus, the probability value of $0.006<0.05$ then $H_{0}$ is rejected, and (4) There is no interaction between the cooperative learning model type Kancing Gemerincing and learning motivation on student learning outcomes in the Political Economy course. This is indicated by the Sig level of 0.205. This means that the value of Sig is greater than the value of $\alpha=0.05$ (sig $\alpha$ ), so the null hypothesis (Ho) is accepted.
\end{abstract}

Keyword: Kancing Gemerincing; Learning Motivation; Learning Outcomes

\section{PENDAHULUAN}

Pendidikan memegang peranan yang sangat penting untuk menjamin kelangsungan hidup Negara dan Bangsa, karena pendidikan merupakan wahana untuk meningkatkan dan mengembangkan kualitas Sumber Daya Manusia (SDM). Oleh karena itu, dapat dikatakan bahwa pendidikan menduduki posisi sentral dalam semua bidang pembangunan. Sasaran pendidikan adalah untuk meningkatkan kualitas SDM yang relevan. Jika pendidikan tidak mengikuti perubahan yang terjadi pada masa tertentu, maka pendidikan akan selalu ketinggalan zaman.

Salah satu upaya pemerintah untuk meningkatkan mutu pendidikan dengan dikeluarkannya Peraturan Pemerintah No. 19 Tahun 2005 tentang Standar Nasional Pendidikan, yang meliputi standar isi, standar proses, standar kompetensi lulusan, standar pendidik dan tenaga kependidikan, dan standar penilaian kependidikan. Standar proses yang ditetapkan dalam peraturan pemerintah di atas diarahkan agar peserta didik dapat mengembangkan potensi dirinya dengan mewujudkan suasana belajar yang interaktif, inspiratif, menyenangkan, menantang, memotivasi peserta didik untuk berpartisipasi secara aktif, serta memiliki kepribadian, akhlak mulia dan keterampilan yang diperlukan dirinya, masyarakat, bangsa dan negara.

Banyak cara yang dapat dilakukan untuk meningkatkan kualitas pembelajaran terutama pada mata kuliah Ekonomi Politik. Salah satunya dengan pemilihan model pembelajaran. Pada proses pembelajaran, dosen harus menggunakan model pembelajaran yang memungkinkan mahasiswa dapat berpartisipasi aktif dalam belajar. Proses interaksi ini akan berjalan baik kalau mahasiswa lebih banyak aktif dibandingkan dengan dosen. Model pembelajaran yang baik adalah model yang dapat menumbuhkan kegiatan belajar mahasiswa. 
Diliza Afrila, Pengaruh Model Pembelajaran Kooperatif Tipe Kancing Gemerincing dan Motivasi Belajar terhadap Hasil Belajar Mahasiswa pada Mata Kuliah Ekonomi Politik di Program Studi Pendidikan Ekonomi Fakultas Keguruan dan Ilmu Pendidikan Universitas Batanghari Jambi

Berdasarkan pengamatan penulis, dosen pengampu mata kuliah Ekonomi Politik pada Tahun Akademik 2018/2019 belum menggunakan model pembelajaran yang mampu meningkatkan motivasi belajar dan hasil belajar mahasiswa. Padahal, model dan metode pembelajaran yang digunakan oleh dosen merupakan alat untuk menciptakan proses pembelajaran yang mampu memacu interaksi edukatif. Model dan metode pembelajaran yang dipilih dosen akan sangat menentukan efektifitas proses pembelajaran yang dikelolanya.

Selama ini, proses pembelajaran di dalam kelas cenderung menggunakan komunikasi verbal atau metode ceramah. Dimana, proses pembelajaran didominasi/ terfokus pada dosen (teacher centered), pemahaman mahasiswa hanya bersifat faktual seperti siapa, apa, kapan dan sebagainya, mereka tidak dapat berfikir secara kritis. Selain itu, pembelajaran tidak mengaktifkan mahasiswa untuk membangun pengetahuannya sendiri dengan mencari informasi dari luar kelas, sumbersumber seperti (institusi, orang) yang menawarkan sederetan gagasan, opini, data, solusi yang berkaitan dengan masalah yang sedang dipelajari serta kurangnya komunikasi dan interaksi antar mahasiswa dalam pemerataan tanggung jawab dalam kelompok.

Berdasarkan fenomena yang terjadi, maka penulis ingin menerapkan suatu metode yang bervariasi yang dapat meningkatkan kreativitas dan keaktifan mahasiswa dalam belajar. Dengan diterapkannya variasi metode pembelajaran diharapkan mahasiswa lebih memahami materi yang diberikan sehingga bisa mendapatkan hasil yang baik dan dapat menerapkannya dalam kehidupan sehari- hari. Salah satu upaya yang dapat dilakukan adalah dengan model pembelajaran kooperatif. Dimana, pembelajaran kooperatif adalah pembelajaran yang membuat kelompok belajar atau melibatkan mahasiswa dalam diskusi kelompok.

Salah satu tipe dalam model pembelajaran kooperatif adalah Kancing Gemerincing. Model pembelajaran ini mampu mengatasi hambatan pemerataan kesempatan yang sering mewarnai kerja kelompok. Dalam kebanyakan kelompok, sering kali ada satu anak atau anggota yang terlalu dominan dan banyak bicara. Sebaliknya, ada anak yang pasif dan pasrah saja pada rekannya yang lebih dominan.

Adapun tujuan penelitian ini adalah untuk mengetahui (1) Hasil belajar mahasiswa pada mata kuliah Ekonomi Politik yang diajar dengan menggunakan model pembelajaran kooperatif tipe Kancing Gemerincing lebih tinggi dari pada mahasiswa yang diajar dengan menggunakan model pembelajaran konvensional di Program Studi Pendidikan Ekonomi Fakultas Keguruan dan Ilmu Pendidikan Universitas Batanghari Jambi, (2) Hasil belajar mahasiswa pada mata kuliah Ekonomi Politik yang memiliki motivasi belajar tinggi yang diajar dengan menggunakan model pembelajaran kooperatif tipe Kancing Gemerincing lebih tinggi dari pada mahasiswa yang memiliki motivasi belajar tinggi yang diajar dengan model pembelajaran konvensional di Program Studi Pendidikan Ekonomi Fakultas Keguruan dan Ilmu Pendidikan Universitas Batanghari Jambi, (3) Hasil belajar mahasiswa pada mata kuliah Ekonomi Politik yang memiliki motivasi belajar rendah yang diajar dengan menggunakan model pembelajaran kooperatif tipe Kancing Gemerincing lebih tinggi dari pada mahasiswa yang memiliki motivasi belajar rendah yang diajar dengan model pembelajaran konvensional di Program Studi Pendidikan Ekonomi Fakultas Keguruan dan Ilmu Pendidikan Universitas Batanghari Jambi, dan (4) Interaksi antara model pembelajaran kooperatif tipe Kancing Gemerincing dengan motivasi belajar terhadap hasil belajar mahasiswa pada mata kuliah Ekonomi Politik di Program Studi Pendidikan Ekonomi Fakultas Keguruan dan Ilmu Pendidikan Universitas Batanghari Jambi.

\section{METODE}

Penelitian yang peneliti laksanakan ini adalah eksperimen semu (quasi experiment). Menurut Trianto (2010) "Penelitian eksperimen dapat didefenisikan sebagai metode sistematis guna membangun hubungan yang mengandung fenomena sebab akibat". Adapun populasi penelitian ini adalah mahasiswa Program Studi Pendidikan Ekonomi Semester VI/A1 dan VI/A2 Tahun Akademik 2019/2020, yang berjumlah 27 orang. Teknik pengambilan sampel pada penelitian ini adalah Purposive Sampling (sampel bertujuan). Adapun teknik pengumpulan data pada penelitian ini adalah dengan menyebarkan angket kepada responden penelitian dan butir soal.

\section{HASIL DAN PEMBAHASAN \\ Deskripsi Variabel Penelitian}

Untuk mengetahui hasil penelitian tentang penerapan model pembelajaran kooperatif tipe Kancing Gemerincing dan motivasi belajar terhadap hasil belajar mahasiswa pada mata kuliah Ekonomi Politik, maka dari hasil pengolahan data untuk masing-masing variabel dilakukan deskripsi dengan tujuan untuk menggambarkan proporsi jawaban responden terhadap penelitian sebagai berikut:

\section{Distribusi Frekuensi Variabel Motivasi Belajar 1. Motivasi Belajar Kelas Eksperimen}

Secara keseluruhan rata-rata skor motivasi belajar mahasiswa kelas eksperimen adalah 4,81 dengan TCR 96,21\%. Artinya, motivasi belajar mahasiswa berada pada kategori sangat baik. 
Diliza Afrila, Pengaruh Model Pembelajaran Kooperatif Tipe Kancing Gemerincing dan Motivasi Belajar terhadap Hasil Belajar Mahasiswa pada Mata Kuliah Ekonomi Politik di Program Studi Pendidikan Ekonomi Fakultas Keguruan dan Ilmu Pendidikan Universitas Batanghari Jambi

Tabel 1. Rata-rata Skor Motivasi Belajar Mahasiswa Kelas Eksperimen

\begin{tabular}{|c|c|c|c|c|}
\hline No. & $\begin{array}{r} \\
\text { Pernyataan }\end{array}$ & Mean & TCR & Kategori \\
\hline 1. & Saya hadir mengikuti perkuliahan tepat waktu & 5,00 & 100,00 & Sangat Baik \\
\hline 2. & Saya mengikuti perkuliahan sampai jam pelajaran berakhir & 5,00 & 100,00 & Sangat Baik \\
\hline 3. & Saya merasa senang apabila dosen tidak dating & 4,93 & 98,67 & Sangat Baik \\
\hline 4. & Saya mengulang kembali materi pelajaran di rumah & 4,87 & 97,33 & Sangat Baik \\
\hline 5. & Saya tidak cepat putus asa ketika mengalami kesulitan dalam belajar & 4,73 & 94,67 & Sangat Baik \\
\hline 6. & Saya mengerjakan tugas yang diberikan oleh dosen dengan baik dan sungguh-sungguh & 4,67 & 93,33 & Sangat Baik \\
\hline 7. & Saya malas belajar ketika menghadapi kesulitan & 4,80 & 96,00 & Sangat Baik \\
\hline 8. & Saya bersemangat memperhatikan materi pelajaran yang disampaikan oleh dosen & 4,87 & 97,33 & Sangat Baik \\
\hline 9. & Saya berkonsentrasi dalam belajar & 4,80 & 96,00 & Sangat Baik \\
\hline 10. & Saya merasa terpaksa mengikuti pelajaran & 4,80 & 96,00 & Sangat Baik \\
\hline 11. & Saya mengerjakan tugas yang diberikan oleh dosen sendiri & 4,80 & 96,00 & Sangat Baik \\
\hline 12. & Saya mengerjakan tugas dengan cara menyontek pekerjaan teman & 4,73 & 94,67 & Sangat Baik \\
\hline 13. & Saya belajar setiap hari meskipun tidak ada ulangan & 5,00 & 100,00 & Sangat Baik \\
\hline 14. & Saya keluar masuk kelas karena bosan belajar & 5,00 & 100,00 & Sangat Baik \\
\hline 15. & Saya suka apabila dosen memberikan tugas dengan model yang berbeda dengan sebelumnya & 4,93 & 98,67 & Sangat Baik \\
\hline 16. & Saya menjawab pertanyaan dosen sesuai dengan pendapat yang saya yakini & 5,00 & 100,00 & Sangat Baik \\
\hline 17. & Saya malas menanggapi pertanyaan dari dosen & 4,73 & 94,67 & Sangat Baik \\
\hline 18. & Saya dapat menerima saran/kritikan dari teman & 4,73 & 94,67 & Sangat Baik \\
\hline 19. & Saya berani mengerjakan soal di depan kelas & 4,80 & 96,00 & Sangat Baik \\
\hline 20. & Saya berani menerangkan kembali materi pelajaran di depan kelas & 4,60 & 92,00 & Sangat Baik \\
\hline 21. & Saya mudah terpengaruh oleh jawaban teman dalam mengerjakan tugas & 4,60 & 92,00 & Sangat Baik \\
\hline 22. & Saya menghadapi masalah dalam belajar dengan tenang & 4,60 & 92,00 & Sangat Baik \\
\hline 23. & Ketika menghadapi soal-soal yang sulit saya berusaha mencari jawabannya & 4,73 & 94,67 & Sangat Baik \\
\hline 24. & Saya tidak suka mencari dan menyelesaikan soal-soal yang belum diajarkan oleh dosen & 4,87 & 97,33 & Sangat Baik \\
\hline 25. & Saya malas mengerjakan latihan soal apabila dosen tidak memintanya & 4,67 & 93,33 & Sangat Baik \\
\hline
\end{tabular}

\section{Motivasi Belajar Kelas Kontrol}

Secara keseluruhan rata-rata skor motivasi belajar mahasiswa kelas kontrol adalah 4,78 dengan TCR
95,53\%. Artinya, motivasi belajar mahasiswa berada pada kategori sangat baik.

Tabel 2. Rata-rata Skor Motivasi Belajar Mahasiswa Kelas Kontrol

\begin{tabular}{|c|c|c|c|c|}
\hline No. & Pernyataan & Mean & TCR & Kategori \\
\hline 1. & Saya hadir mengikuti perkuliahan tepat waktu & 4,92 & 98,33 & Sangat Baik \\
\hline 2. & Sava mengikuti perkuliahan sampai jam pelajaran berakhir & 4,83 & 96,67 & Sangat Baik \\
\hline 3. & Saya merasa senang apabila dosen tidak dating & 4,92 & 98,33 & Sangat Baik \\
\hline 4. & Saya mengulang kembali materi pelajaran di rumah & 4,75 & 95,00 & Sangat Baik \\
\hline 5. & Saya tidak cepat putus asa ketika mengalami kesulitan dalam belajar & 4,92 & 98,33 & Sangat Baik \\
\hline 6. & Saya mengerjakan tugas yang diberikan oleh dosen dengan baik dan sungguh-sungguh & 4,83 & 96,67 & Sangat Baik \\
\hline 7. & Saya malas belajar ketika menghadapi kesulitan & 4,92 & 98,33 & Sangat Baik \\
\hline 8. & Saya bersemangat memperhatikan materi pelajaran yang disampaikan oleh dosen & 4,83 & 96,67 & Sangat Baik \\
\hline 9. & Saya berkonsentrasi dalam belajar & 4,75 & 95,00 & Sangat Baik \\
\hline 10. & Saya merasa terpaksa mengikuti pelajaran & 4,75 & 95,00 & Sangat Baik \\
\hline 11. & Saya mengerjakan tugas yang diberikan oleh dosen sendiri & 4,83 & 96,67 & Sangat Baik \\
\hline 12. & Saya mengerjakan tugas dengan cara menyontek pekerjaan teman & 4,67 & 93,33 & Sangat Baik \\
\hline 13. & Saya belajar setiap hari meskipun tidak ada ulangan & 5,00 & 100,00 & Sangat Baik \\
\hline 14. & Saya keluar masuk kelas karena bosan belajar & 4,92 & 98,33 & Sangat Baik \\
\hline 15. & Saya suka apabila dosen memberikan tugas dengan model yang berbeda dengan sebelumnya & 4,75 & 95,00 & Sangat Baik \\
\hline 16. & Saya menjawab pertanyaan dosen sesuai dengan pendapat yang saya yakini & 4,92 & 98,33 & Sangat Baik \\
\hline 17. & Saya malas menanggapi pertanyaan dari dosen & 4,58 & 91,67 & Sangat Baik \\
\hline 18. & Saya dapat menerima saran/kritikan dari teman & 4,67 & 93,33 & Sangat Baik \\
\hline 19. & Saya berani mengerjakan soal di depan kelas & 4,75 & 95,00 & Sangat Baik \\
\hline 20. & Saya berani menerangkan kembali materi pelajaran di depan kelas & 4,50 & 90,00 & Sangat Baik \\
\hline 21. & Saya mudah terpengaruh oleh jawaban teman dalam mengerjakan tugas & 4,50 & 90,00 & Sangat Baik \\
\hline 22. & Saya menghadapi masalah dalam belajar dengan tenang & 4,75 & 95,00 & Sangat Baik \\
\hline 23. & Ketika menghadapi soal-soal yang sulit saya berusaha mencari jawabannya & 4,75 & 95,00 & Sangat Baik \\
\hline 24. & Saya tidak suka mencari dan menyelesaikan soal-soal yang belum diajarkan oleh dosen & 4,67 & 93,33 & Sangat Baik \\
\hline 25. & Saya malas mengerjakan latihan soal apabila dosen tidak memintanya & 4,75 & 95,00 & Sangat Baik \\
\hline
\end{tabular}

\section{Distribusi Frekuensi Variabel Hasil Belajar}

Data hasil belajar diambil dari hasil tes akhir yang dilakukan setelah menerapkan masing-masing metode di masing-masing kelas. Kelas eksperimen dengan menggunakan model pembelajaran kooperatif tipe
Kancing Gemerincing. Sedangkan, kelas kontrol dengan menggunakan metode konvensional. Tes akhir berbentuk tes pilihan ganda yang berjumlah 25 item pilihan ganda dengan rentangan nilai $0-100$. Data hasil belajar mahasiswa dapat dilihat dari tabel berikut: 
Diliza Afrila, Pengaruh Model Pembelajaran Kooperatif Tipe Kancing Gemerincing dan Motivasi Belajar terhadap Hasil Belajar Mahasiswa pada Mata Kuliah Ekonomi Politik di Program Studi Pendidikan Ekonomi Fakultas Keguruan dan Ilmu Pendidikan Universitas Batanghari Jambi

Tabel 3. Distribusi Frekuensi Perbandingan Hasil Belajar Kelas Eksperimen dan Kontrol

\begin{tabular}{|c|c|c|c|c|c|c|c|}
\hline \multirow[t]{2}{*}{ No. } & \multirow[t]{2}{*}{$\begin{array}{c}\text { Kelas } \\
\text { Interval }\end{array}$} & \multicolumn{2}{|c|}{$\begin{array}{c}\text { Kelas } \\
\text { Eksperimen }\end{array}$} & \multirow[t]{2}{*}{ No. } & \multirow[t]{2}{*}{$\begin{array}{c}\text { Kelas } \\
\text { Interval }\end{array}$} & \multicolumn{2}{|c|}{$\begin{array}{c}\text { Kelas } \\
\text { Kontrol }\end{array}$} \\
\hline & & $\mathbf{F i}$ & $\%$ & & & Fi & $\%$ \\
\hline 1. & $92-92$ & 3 & 20 & 1. & $84-87$ & 2 & 16,67 \\
\hline 2. & $87-91$ & 2 & 13,33 & 2. & $80-83$ & 4 & 33,33 \\
\hline 3. & $82-86$ & 4 & 26,67 & 3. & $76-79$ & 3 & 25 \\
\hline 4. & $77-81$ & 2 & 13,33 & 4. & $72-75$ & 1 & 8,33 \\
\hline 5. & $72-76$ & 4 & 26,67 & 5. & $68-71$ & 2 & $\begin{array}{c}16,6 \\
7\end{array}$ \\
\hline \multicolumn{2}{|c|}{ Jumlah } & 15 & 100 & \multicolumn{2}{|c|}{ Jumlah } & 12 & 100 \\
\hline \multicolumn{2}{|c|}{ Mean } & \multicolumn{2}{|c|}{83,20} & \multicolumn{2}{|c|}{ Mean } & \multicolumn{2}{|c|}{77,00} \\
\hline \multicolumn{2}{|c|}{ Median } & \multicolumn{2}{|c|}{84,00} & \multicolumn{2}{|c|}{ Median } & \multicolumn{2}{|c|}{78,00} \\
\hline \multicolumn{2}{|c|}{ Modus } & \multicolumn{2}{|c|}{84} & \multicolumn{2}{|c|}{ Modus } & \multicolumn{2}{|c|}{80} \\
\hline \multicolumn{2}{|c|}{ Standar } & \multicolumn{2}{|c|}{7,282} & \multirow{2}{*}{\multicolumn{2}{|c|}{$\begin{array}{l}\text { Standar } \\
\text { Deviasi }\end{array}$}} & \multirow{2}{*}{\multicolumn{2}{|c|}{5,427}} \\
\hline \multicolumn{2}{|c|}{ Deviasi } & & & & & & \\
\hline Vari & Ince & \multicolumn{2}{|c|}{53,029} & \multicolumn{2}{|c|}{ Variance } & \multicolumn{2}{|c|}{29,455} \\
\hline \multicolumn{2}{|c|}{ Range } & \multicolumn{2}{|c|}{24} & \multicolumn{2}{|c|}{ Range } & \multicolumn{2}{|c|}{16} \\
\hline \multicolumn{2}{|c|}{ Maximum } & \multicolumn{2}{|c|}{96} & \multicolumn{2}{|c|}{ Maximum } & \multicolumn{2}{|c|}{84} \\
\hline \multicolumn{2}{|c|}{ Minimum } & & 72 & Min & num & & 68 \\
\hline
\end{tabular}

Sumber: Pengolahan Data Primer, 2020

Berdasarkan tabel 3 dapat dilihat bahwa hasil belajar mahasiswa yang diajar menggunakan model pembelajaran kooperatif tipe Kancing Gemerincing lebih tinggi dibandingkan dengan hasil belajar mahasiswa yang diajar dengan menggunakan metode konvensional. Rata-rata hasil belajar mahasiswa pada kelas eksperimen adalah 83,20 dengan nilai tertinggi yang diperoleh adalah 96 dan nilai terendah yang diperoleh adalah 72 . Sedangkan, rata-rata hasil belajar mahasiswa pada kelas kontrol adalah 77,00 dengan nilai tertinggi yang diperoleh adalah 84 dan nilai terendah yang diperoleh adalah 68

\section{Perbandingan Hasil Belajar Mahasiswa Berdasarkan Motivasi Belajar}

Perbandingan hasil belajar mahasiswa berdasarkan motivasi belajar tinggi dan motivasi belajar rendah pada kelas eksperimen dan kelas kontrol dapat dilihat pada tabel 4 sebagai berikut:

Tabel 4. Perbandingan Hasil Belajar Berdasarkan Motivasi Belajar Tinggi

\begin{tabular}{clcccc}
\hline \multirow{2}{*}{ No. } & Statistik Sampel & \multicolumn{4}{c}{ Motivasi Tinggi } \\
\cline { 3 - 6 } & & \multicolumn{2}{c}{ Kelas Eksperimen } & \multicolumn{2}{c}{ Kelas Kontrol } \\
\cline { 3 - 6 } & & Motivasi & Hasil Belajar & Motivasi & Hasil Belajar \\
\hline 1. & Jumlah Siswa & 4 & 4 & 3 & 3 \\
2. & Mean & 124,00 & 92,00 & 123,67 & 81,33 \\
3. & Median & 124,50 & 92,00 & 123,00 & 80 \\
4. & Modus & 125 & 92 & 123 & 80 \\
5. & Standar Deviasi & 1,414 & 3,266 & 1,155 & 2,309 \\
\hline
\end{tabular}

Sumber: Pengolahan Data Primer, 2020

Berdasarkan data tabel 4 dapat dilihat bahwa hasil belajar mahasiswa yang memiliki motivasi belajar tinggi pada kelas eksperimen lebih tinggi dari pada kelas kontrol. Perolehan data yang diperoleh pada kelas eksperimen yang diajar dengan model pembelajaran kooperatif tipe Kancing Gemerincing dengan rata-rata hasil belajar sebesar 92,00 dengan nilai tengah 92,00 dan nilai yang sering muncul adalah 92. Jadi, dapat disimpulkan bahwa terdapat perbedaan hasil belajar mahasiswa yang memiliki motivasi belajar tinggi pada model pembelajaran kooperatif tipe Kancing Gemerincing dengan motivasi belajar tinggi pada metode konvensional.

Tabel 5. Perbandingan Hasil Belajar Berdasarkan Motivasi Belajar Rendah

\begin{tabular}{clcccc}
\hline \multirow{2}{*}{ No. } & Statistik Sampel & \multicolumn{4}{c}{ Motivasi Rendah } \\
\cline { 3 - 6 } & & \multicolumn{2}{c}{ Kelas Eksperimen } & \multicolumn{2}{c}{ Kelas Kontrol } \\
\cline { 3 - 6 } & & Motivasi & Hasil Belajar & Motivasi & Hasil Belajar \\
\hline 1. & Jumlah Siswa & 4 & 4 & 3 & 3 \\
2. & Mean & 116,50 & 74,00 & 114,00 & 70,67 \\
3. & Median & 116,00 & 74,00 & 115,00 & 68,00 \\
4. & Modus & 115 & 72 & 115 & 68 \\
5. & Standar Deviasi & 1,915 & 2,309 & 1,732 & 4,619 \\
\hline
\end{tabular}

Sumber: Pengolahan Data Primer, 2020

Berdasarkan data tabel 5 dapat dilihat bahwa hasil belajar mahasiswa yang memiliki motivasi belajar rendah pada kelas eksperimen lebih tinggi dari pada kelas kontrol. Perolehan data yang diperoleh pada kelas eksperimen yang diajar dengan model pembelajaran kooperatif tipe Kancing Gemerincing dengan rata-rata hasil belajar sebesar 74,00 dengan nilai tengah 74,00 dan nilai yang sering muncul adalah 72. Jadi, dapat disimpulkan bahwa terdapat perbedaan hasil belajar mahasiswa yang memiliki motivasi belajar rendah pada model pembelajaran kooperatif tipe Kancing Gemerincing dengan motivasi belajar rendah pada metode konvensional.

\section{Uji Persyaratan}

Sebagaimana yang telah diuraikan pada metodologi penelitian, sebelum uji hipotesis maka dilakukan uji normalitas dan uji homogenitas.

\section{Uji Normalitas}

Uji normalitas dilakukan untuk melihat apakah sampel berdistribusi normal atau tidak. Uji normalitas dilakukan dengan menggunakan kolmograf - Smirnov. Hasil analisis pengujian normalitas dari variabel penelitian dapat dilihat pada tabel 6 di bawah ini:

Tabel 6. Hasil Uji Normalitas

One-Sample Kolmogorov-Smirnov Test

\begin{tabular}{|c|c|c|c|c|c|}
\hline & & MBKE & MBKK & HBKE & HBKK \\
\hline $\mathrm{N}$ & & 15 & 12 & 15 & 12 \\
\hline \multirow[t]{2}{*}{ Normal Parameters $^{\mathrm{a}}$} & Mean & 120.27 & 119.42 & 82.80 & 77.83 \\
\hline & Std. Deviation & 3.127 & 3.872 & 6.581 & 5.006 \\
\hline Most Extreme Differences & Absolute & .143 & .159 & .119 & .263 \\
\hline & Positive & .090 & .123 & .116 & .203 \\
\hline & Negative & -.143 & -.159 & -.119 & -.263 \\
\hline Kolmogorov-Smirnov Z & & .553 & .550 & .459 & .912 \\
\hline Asymp. Sig. (2-tailed) & & .920 & .923 & .984 & .376 \\
\hline
\end{tabular}


Diliza Afrila, Pengaruh Model Pembelajaran Kooperatif Tipe Kancing Gemerincing dan Motivasi Belajar terhadap Hasil Belajar Mahasiswa pada Mata Kuliah Ekonomi Politik di Program Studi Pendidikan Ekonomi Fakultas Keguruan dan Ilmu Pendidikan Universitas Batanghari Jambi

Berdasarkan hasil analisis data uji normalitas sebagaimana terlihat pada tabel di atas diketahui bahwa nilai signifikan untuk motivasi belajar kelompok eksperimen sebesar 0,920 dan kelompok kontrol sebesar 0,923 . Jika nilai signifikan dari masing- masing kelas dibandingkan dengan alpha $(\alpha=0,05)$ dimana terlihat signifikan lebih besar dari pada alpha. Dengan demikian dapat dikatakan bahwa data hasil penelitian untuk motivasi belajar berdistribusi normal. Begitu juga hasil belajar mahasiswa baik untuk kelompok eksperimen maupun untuk kelompok kontrol juga berdistribusi normal. Dimana nilai signifikan untuk kelompok eksperimen adalah sebesar 0,984 dan kelompok kontrol sebesar 0,376 .

\section{Uji Homogenitas}

Uji homogenitas dimaksudkan untuk memperlihatkan bahwa dua atau lebih kelompok data sampel berasal dari populasi yang memiliki variansi yang sama. Uji homogenitas digunakan untuk mengetahui apakah motivasi belajar dan hasil belajar mahasiswa memiliki tingkat variansi data yang sama atau tidak. Uji yang digunakan adalah uji Levene. Sebagaimana terlihat pada tabel berikut ini hasil uji homogenitas pada motivasi belajar dan hasil belajar mahasiswa yang diajarkan dengan menggunakan model pembelajaran kooperatif tipe Kancing Gemerincing dan yang diajar dengan model pembelajaran konvensional.

Tabel 7. Hasil Uji Homogenitas Test of Homogeneity of Variances HB

\begin{tabular}{|r|r|r|r|}
\hline Levene Statistic & df1 & df2 & Sig. \\
\hline 2.411 & 1 & 25 & .133 \\
\hline
\end{tabular}

Berdasarkan hasil analisa data untuk uji homogenitas sebagaimana terlihat pada tabel 7 di atas diketahui bahwa nilai Sig adalah sebesar 0,133. Jika nilai signifikansi dibandingkan dengan alpha $(\alpha=0,05)$ maka terlihat nilai signifikan lebih besar dari pada alpha. Dengan demikian dapat dikatakan bahwa data hasil penelitian memiliki variansi yang sama atau homogen.

\section{Uji Hipotesis}

Uji hipotesis dilakukan pada dasarnya untuk menguji apakah terdapat perbedaan hasil belajar mahasiswa yang diajar dengan menggunakan model pembelajaran kooperatif tipe Kancing Gemerincing dengan hasil belajar mahasiswa yang diajar dengan model pembelajaran konvensional, apakah ada perbedaan hasil belajar mahasiswa yang memiliki motivasi belajar tinggi yang diajar dengan model pembelajaran kooperatif tipe Kancing Gemerincing dengan hasil belajar mahasiswa yang diajar dengan model pembelajaran konvensional, serta apakah ada perbedaan hasil belajar mahasiswa yang memiliki motivasi belajar rendah yang diajar dengan model pembelajaran kooperatif tipe Kancing Gemerincing dengan hasil belajar mahasiswa yang diajar dengan model pembelajaran konvensional dan apakah ada interaksi model pembelajaran kooperatif tipe Kancing Gemerincing dan motivasi belajar terhadap hasil belajar.

Setelah dilakukan uji normalitas dan uji homogenitas, ternyata skor hasil belajar mahasiswa pada kelompok eksperimen berdistribusi normal dan memiliki variansi yang homogen. Dengan demikian persyaratan analisis varian (Anava) dapat terpenuhi untuk digunakan pada pengujian hipotesis. Di bawah ini hasil analisis uji hipotesis menggunakan SPSS 20.

\section{Hipotesis Pertama}

Hipotesis pertama penelitian ini adalah hasil belajar mahasiswa pada mata kuliah Ekonomi Politik yang diajar dengan menggunakan model pembelajaran kooperatif tipe Kancing Gemerincing secara signifikan lebih tinggi dari pada mahasiswa yang diajar dengan menggunakan model pembelajaran konvensional di Program Studi Pendidikan Ekonomi Fakultas Keguruan dan Ilmu Pendidikan Universitas Batanghari Jambi.

Tabel 8. Hasil Analisis Uji t Hasil Belajar Mahasiswa Diajar dengan Model Pembelajaran Kooperatif Tipe Kancing Gemerincing dengan Konvensional

Independent Samples Test

\begin{tabular}{|c|c|c|c|c|c|c|c|c|c|}
\hline & \multicolumn{2}{|c|}{$\begin{array}{c}\text { Levene's Test for Equality } \\
\text { of Variances }\end{array}$} & \multicolumn{7}{|c|}{ t-test for Equality of Means } \\
\hline & \multirow[t]{2}{*}{$\mathrm{F}$} & \multirow[t]{2}{*}{ Sig. } & \multirow[t]{2}{*}{$\mathrm{T}$} & \multirow[t]{2}{*}{ df } & \multirow[t]{2}{*}{$\begin{array}{l}\text { Sig. (2- } \\
\text { tailed) }\end{array}$} & \multirow[t]{2}{*}{$\begin{array}{c}\text { Mean } \\
\text { Difference }\end{array}$} & \multirow[t]{2}{*}{$\begin{array}{l}\text { Std. Error } \\
\text { Difference }\end{array}$} & \multicolumn{2}{|c|}{$\begin{array}{l}\text { 95\% Confidence Interval of } \\
\text { the Difference }\end{array}$} \\
\hline & & & & & & & & Lower & Upper \\
\hline $\begin{array}{l}\text { HB Equal variances } \\
\text { assumed }\end{array}$ & 2.411 & .133 & 2.159 & 25 & .041 & 4.967 & 2.301 & .229 & 9.705 \\
\hline $\begin{array}{l}\text { Equal variances not } \\
\text { assumed }\end{array}$ & & & 2.227 & 24.958 & .035 & 4.967 & 2.231 & .372 & 9.561 \\
\hline
\end{tabular}


Diliza Afrila, Pengaruh Model Pembelajaran Kooperatif Tipe Kancing Gemerincing dan Motivasi Belajar terhadap Hasil Belajar Mahasiswa pada Mata Kuliah Ekonomi Politik di Program Studi Pendidikan Ekonomi Fakultas Keguruan dan Ilmu Pendidikan Universitas Batanghari Jambi

Tabel 8 menunjukkan bahwa nilai thitung 2,159 dan nilai probabilitas 0,041 . Sehingga nilai probabilitas $0,041<0,05$ maka $\mathrm{H}_{0}$ ditolak. Artinya, hasil belajar mahasiswa dengan menggunakan model pembelajaran kooperatif tipe Kancing Gemerincing mempunyai perbedaan yang signifikan pada taraf signifikansi 0,05 . Hal ini berarti bahwa hasil belajar mahasiswa yang diajar dengan menggunakan model pembelajaran kooperatif tipe Kancing Gemerincing lebih tinggi dari pada mahasiswa yang diajar dengan menggunakan model pembelajaran konvensional pada taraf signifikansi 0,05 .

\section{Hipotesis Kedua}

Hipotesis kedua penelitian ini adalah hasil belajar mahasiswa pada mata kuliah Ekonomi Politik yang memiliki motivasi belajar tinggi yang diajar dengan menggunakan model pembelajaran kooperatif tipe Kancing Gemerincing secara signifikan lebih tinggi dari pada mahasiswa yang memiliki motivasi belajar tinggi yang diajar dengan model pembelajaran konvensional di Program Studi Pendidikan Ekonomi Fakultas Keguruan dan Ilmu Pendidikan Universitas Batanghari Jambi.

Tabel 9. Hasil Analisis Uji t Hasil Belajar Mahasiswa yang Memiliki Motivasi Belajar Tinggi Independent Samples Test

\begin{tabular}{|c|c|c|c|c|c|c|c|c|c|}
\hline & \multicolumn{2}{|c|}{$\begin{array}{c}\text { Levene's Test for Equality } \\
\text { of Variances }\end{array}$} & \multicolumn{7}{|c|}{ t-test for Equality of Means } \\
\hline & \multirow[t]{2}{*}{$\mathrm{F}$} & \multirow[t]{2}{*}{ Sig. } & \multirow[t]{2}{*}{$\mathrm{t}$} & \multirow[t]{2}{*}{$\mathrm{df}$} & \multirow[t]{2}{*}{$\begin{array}{l}\text { Sig. (2- } \\
\text { tailed) }\end{array}$} & \multirow[t]{2}{*}{$\begin{array}{c}\text { Mean } \\
\text { Difference }\end{array}$} & \multirow[t]{2}{*}{$\begin{array}{l}\text { Std. Error } \\
\text { Difference }\end{array}$} & \multicolumn{2}{|c|}{$\begin{array}{l}95 \% \text { Confidence Interval of the } \\
\text { Difference }\end{array}$} \\
\hline & & & & & & & & Lower & Upper \\
\hline $\begin{array}{l}\text { HB Equal variances } \\
\text { assumed }\end{array}$ & 1.394 & .291 & 7.260 & 5 & .001 & 9.167 & 1.263 & 5.921 & 12.413 \\
\hline $\begin{array}{l}\text { Equal variances not } \\
\text { assumed }\end{array}$ & & & 7.857 & 4.890 & .001 & 9.167 & 1.167 & 6.147 & 12.186 \\
\hline
\end{tabular}

Tabel 9 menunjukkan bahwa nilai $t_{\text {hitung }} 7,260$ dan nilai probabilitas 0,001 . Sehingga, nilai probabilitas $0,001<0,05$ maka $\mathrm{H}_{0}$ ditolak. Artinya, hasil belajar mahasiswa dengan menggunakan model pembelajaran kooperatif tipe Kancing Gemerincing mempunyai perbedaan yang signifikan pada taraf signifikansi 0,05 . Artinya, mahasiswa yang memiliki motivasi belajar tinggi yang diajar dengan model pembelajaran kooperatif tipe Kancing Gemerincing memiliki perbedaan hasil belajar mahasiswa diajar dengan model pembelajaran konvensional dengan motivasi belajar tinggi.

Hal ini menunjukkan bahwa hasil belajar mahasiswa yang memiliki motivasi belajar tinggi yang diajar dengan menggunakan model pembelajaran kooperatif tipe Kancing Gemerincing lebih tinggi dari pada mahasiswa yang memiliki motivasi belajar tinggi yang diajar dengan model pembelajaran konvensional pada taraf signifikansi 0,05 .

\section{Hipotesis Ketiga}

Hipotesis ketiga penelitian ini adalah hasil belajar mahasiswa pada mata kuliah Ekonomi Politik yang memiliki motivasi belajar rendah yang diajar dengan menggunakan model pembelajaran kooperatif tipe Kancing Gemerincing secara signifikan lebih tinggi dari pada mahasiswa yang memiliki motivasi belajar rendah yang diajar dengan model pembelajaran konvensional di Program Studi Pendidikan Ekonomi Fakultas Keguruan dan Ilmu Pendidikan Universitas Batanghari Jambi.

Tabel 10. Hasil Analisis Uji t Hasil Belajar Mahasiswa yang Memiliki Motivasi Belajar Rendah Independent Samples Test

\begin{tabular}{|c|c|c|c|c|c|c|c|c|c|}
\hline & \multicolumn{2}{|c|}{$\begin{array}{c}\text { Levene's Test for Equality } \\
\text { of Variances }\end{array}$} & \multicolumn{7}{|c|}{ t-test for Equality of Means } \\
\hline & \multirow[t]{2}{*}{$\mathrm{F}$} & \multirow[t]{2}{*}{ Sig. } & \multirow[t]{2}{*}{$\mathrm{t}$} & \multirow[t]{2}{*}{ df } & \multirow[t]{2}{*}{$\begin{array}{l}\text { Sig. (2- } \\
\text { tailed) }\end{array}$} & \multirow[t]{2}{*}{$\begin{array}{c}\text { Mean } \\
\text { Difference }\end{array}$} & \multirow[t]{2}{*}{$\begin{array}{l}\text { Std. Error } \\
\text { Difference }\end{array}$} & \multicolumn{2}{|c|}{$\begin{array}{l}95 \% \text { Confidence Interval of the } \\
\text { Difference }\end{array}$} \\
\hline & & & & & & & & Lower & Upper \\
\hline $\begin{array}{l}\text { HB Equal variances } \\
\text { assumed }\end{array}$ & 5.373 & .068 & 1.532 & 5 & .006 & 3.833 & 2.502 & 2.599 & 10.265 \\
\hline $\begin{array}{l}\text { Equal variances not } \\
\text { assumed }\end{array}$ & & & 1.353 & 2.521 & .005 & 3.833 & 2.833 & 6.235 & 13.902 \\
\hline
\end{tabular}

Tabel 10 menunjukkan bahwa nilai $t_{\text {hitung }} 1,532$ dan nilai probabilitas 0,006 . Sehingga, nilai probabilitas
$0,006<0,05$ maka $\mathrm{H}_{0}$ ditolak. Artinya, mahasiswa yang memiliki motivasi belajar rendah yang diajar dengan 
Diliza Afrila, Pengaruh Model Pembelajaran Kooperatif Tipe Kancing Gemerincing dan Motivasi Belajar terhadap Hasil Belajar Mahasiswa pada Mata Kuliah Ekonomi Politik di Program Studi Pendidikan Ekonomi Fakultas Keguruan dan Ilmu Pendidikan Universitas Batanghari Jambi

model pembelajaran kooperatif tipe Kancing Gemerincing memiliki perbedaan hasil belajar mahasiswa diajar dengan model pembelajaran konvensional dengan motivasi belajar rendah.

Hal ini menunjukkan bahwa hasil belajar mahasiswa yang memiliki motivasi belajar rendah yang diajar dengan menggunakan model pembelajaran kooperatif tipe Kancing Gemerincing lebih tinggi dari pada mahasiswa yang memiliki motivasi belajar rendah yang diajar dengan model pembelajaran konvensionalpada taraf signifikansi 0,05.

\section{Hipotesis Keempat}

Hipotesis keempat pada penelitian ini adalah Interaksi antara model pembelajaran kooperatif tipe Kancing Gemerincing dengan motivasi belajar signifikan terhadap hasil belajar mahasiswa pada mata kuliah Ekonomi Politik di Program Studi Pendidikan Ekonomi Fakultas Keguruan dan Ilmu Pendidikan Universitas Batanghari Jambi.

Tabel 11. Hasil Analisis Varian Untuk Interaksi Model Pembelajaran dengan Motivasi Belajar Tests of Between-Subjects Effects

Dependent Variable:HB

\begin{tabular}{|c|c|c|c|c|c|}
\hline Source & Type III Sum of Squares & df & Mean Square & $\mathrm{F}$ & Sig. \\
\hline Corrected Model & $951.852^{\mathrm{a}}$ & 15 & 63.457 & 7.374 & .001 \\
\hline Intercept & 136193.665 & 1 & 136193.665 & $1.583 \mathrm{E} 4$ & .000 \\
\hline MODEL & 78.019 & 1 & 78.019 & 9.066 & .012 \\
\hline MOTIVASI & 667.466 & 10 & 66.747 & 7.756 & .001 \\
\hline MODEL * MOTIVASI & 60.902 & 4 & 15.225 & 1.769 & .205 \\
\hline Error & 94.667 & 11 & 8.606 & & \\
\hline Total & 176416.000 & 27 & & & \\
\hline Corrected Total & 1046.519 & 26 & & & \\
\hline
\end{tabular}

a. $\mathrm{R}$ Squared = ,910 (Adjusted R Squared =,786)

Hasil perhitungan anova dua jalur untuk pengujian hipotesis keempat terlihat pada tabel 11 yang menunjukkan bahwa interaksi antara model pembelajaran dengan motivasi belajar diperolah level Sig 0,205. Ini berarti bahwa nilai Sig lebih besar dari nilai $\alpha=0,05(\operatorname{sig} \alpha)$ maka hipotesis nol $\left(\mathrm{H}_{\mathrm{o}}\right)$ diterima, sehingga tidak terdapat interaksi model pembelajaran kooperatif tipe Kancing Gemerincing dan motivasi belajar terhadap hasil belajar mahasiswa.

\section{Pembahasan}

Hasil Belajar Mahasiswa pada Mata Kuliah Ekonomi Politik yang Diajar dengan Menggunakan Model Pembelajaran Kooperatif Tipe Kancing Gemerincing Secara Signifikan Lebih Tinggi daripada Mahasiswa yang Diajar dengan Menggunakan Model Pembelajaran Konvensional di Program Studi Pendidikan Ekonomi Fakultas Keguruan dan Ilmu Pendidikan Universitas Batanghari Jambi

Model pembelajaran kooperatif tipe Kancing Gemerincing merupakan model yang diterapkan pada penelitian ini. Model pembelajaran ini diduga dapat meningkatkan motivasi belajar dan hasil belajar mahasiswa. Hasil pengujian hipotesis menunjukkan bahwa mahasiswa pada kelas eksperimen yang diajar dengan menggunakan model pembelajaran kooperatif tipe Kancing Gemerincing memperoleh hasil belajar yang lebih tinggi dibanding hasil belajar mahasiswa pada kelas kontrol yang diajar dengan menggunakan model pembelajaran konvensional. Hasil penelitian ini didukung oleh hasil penelitian yang dilakukan oleh Sucipta, dkk (2018) yang menemukan bahwa $t_{\text {hitung }}$ $(3,65)>t_{\text {tabel }}(2,01)$, sehingga $\mathrm{H}_{0}$ ditolak dan $\mathrm{H}_{1}$ diterima yang berarti terdapat pengaruh yang signifikan. Rerata hasil belajar IPA pada kelompok eksperimen, yaitu 14,12 dan kelompok kontrol, yaitu 9,75. Dengan demikian, dapat disimpulkan bahwa penerapan model pembelajaran kooperatif tipe Kancing Gemerincing berpengaruh positif terhadap hasil belajar IPA siswa kelas V Gugus IV Kecamatan Sidemen tahun pelajaran 2017/2018.

Hasil Belajar Mahasiswa pada Mata Kuliah Ekonomi Politik yang Memiliki Motivasi Belajar Tinggi yang Diajar dengan Menggunakan Model Pembelajaran Kooperatif Tipe Kancing Gemerincing Secara Signifikan Lebih Tinggi daripada Mahasiswa yang Memiliki Motivasi Belajar Tinggi yang Diajar dengan Model Pembelajaran Konvensional di Program Studi Pendidikan Ekonomi Fakultas Keguruan dan Ilmu Pendidikan Universitas Batanghari Jambi

Berdasarkan pengujian hipotesis dapat terlihat bahwa terdapat perbedaan hasil belajar mahasiswa yang memiliki motivasi tinggi pada kelas eksperimen dan kelas kontrol. Pada kelas eksperimen diterapkan model 
Diliza Afrila, Pengaruh Model Pembelajaran Kooperatif Tipe Kancing Gemerincing dan Motivasi Belajar terhadap Hasil Belajar Mahasiswa pada Mata Kuliah Ekonomi Politik di Program Studi Pendidikan Ekonomi Fakultas Keguruan dan Ilmu Pendidikan Universitas Batanghari Jambi

pembelajaran kooperatif tipe Kancing Gemerincing dan memperoleh hasil belajar yang lebih tinggi daripada mahasiswa yang diajar dengan menggunakan model pembelajaran konvensional. Hal tersebut dikarenakan mahasiswa yang memiliki motivasi belajar tinggi di kelas eksperimen diajar dengan menggunakan model pembelajaran yang bisa mengaktifkan mahasiswa, semakin aktif seorang mahasiswa untuk mempelajari suatu hal maka akan semakin mendalam pemahaman mahasiswa terhadap materi yang ia pelajari. Berbeda halnya dengan kelas kontrol yang diajar dengan model pembelajaran konvensional. Mahasiswa yang memiliki motivasi belajar tinggi tetapi diajar dengan menggunakan model pembelajaran konvensional memperoleh hasil belajar yang lebih rendah. Hal ini dikarenakan mahasiswa hanya menerima dari dosen, tanpa mereka sendiri aktif dalam memahami suatu hal.

Boekaerts (2002) menyatakan bahwa "It is often stated that bad teaching kills motivation and that good teaching brings out the best in students of all ages". Penyataan ini memiliki makna bahwa cara mengajar yang kurang baik atau tidak sesuai dengan kondisi mahasiswa dapat membunuh motivasi belajar mahasiswa. Sebaliknya, cara mengajar yang baik dapat mengeluarkan kemampuan terbaik mahasiswa dalam mengikuti proses pembelajaran. Meskipun sama-sama memiliki motivasi belajar tinggi, jika cara dosen mengajar (metode yang digunakan) berbeda akan memberikan hasil belajar yang berbeda pula.

Glynn, Aultman dan Owens

mengemukakan bahwa:

Motivation is an internal state that arouses, directs, and sustains human behavior. It plays a fundamental role in learning. Today, more than ever, student motivation is an area of discussion and debate-an area constantly in need of innovative approaches because the societal factors that play a role in motivation are constantly changing.

Pernyataan ini menyiratkan bahwa motivasi merupakan sesuatu yang muncul secara langsung dari dalam diri yang menopang perilaku manusia. Namun, motivasi tersebut juga bisa berubah karena dipengaruhi oleh faktor sosial sehingga diperlukan suatu pendekatan inovatif. Pendekatan inovatif yang bisa digunakan dalam proses pembelajaran salah satunya adalah model pembelajaran kooperatif.

Hasil Belajar Mahasiswa pada Mata Kuliah Ekonomi Politik yang Memiliki Motivasi Belajar Rendah yang Diajar dengan Menggunakan Model Pembelajaran Kooperatif Tipe Kancing Gemerincing Secara Signifikan Lebih Tinggi daripada Mahasiswa yang Memiliki Motivasi Belajar Rendah yang Diajar dengan Model Pembelajaran Konvensional di
Program Studi Pendidikan Ekonomi Fakultas Keguruan dan Ilmu Pendidikan Universitas Batanghari Jambi

Pada pengujian hipotesis ketiga diketahui bahwa hasil belajar mahasiswa yang memiliki motivasi belajar rendah diajar dengan menggunakan model pembelajaran kooperatif tipe Kancing Gemerincing lebih tinggi dibanding hasil belajar mahasiswa yang diajar dengan model pembelajaran konvensional. Pada mahasiswa yang memiliki motivasi rendah pada kelas eksperimen dapat memahami materi lebih dari kelas kontrol karena diajar dengan menggunakan model pembelajaran kooperatif tipe Kancing Merincing. Sehingga, mahasiswa memiliki pemahaman awal dan selama proses pembelajaran mahasiswa harus mengaktifkan diri agar bisa mempunyai peran selama proses pembelajaran.

Kiswoyowati (2011) mengemukakan bahwa motivasi belajar merupakan keseluruhan daya penggerak di dalam diri mahasiswa yang menimbulkan kegiatan belajar, yang menjamin kelangsungan dari kegiatan belajar dan yang memberikan arah pada kegiatan belajar, sehingga tujuan yang dikehendaki dapat dicapai. Apabila daya penggerak dalam diri siswa masih lemah sehingga akan berakibat pada hasil belajar mahasiswa maka akan berakibat motivasi belajar menjadi rendah. Pada mahasiswa yang memiliki motivasi belajar rendah yang diajar dengan menggunakan model pembelajaran kooperatif tipe Kancing Gemerincing diarahkan untuk memahami terlebih dahulu materi pelajaran yang akan diajarkan.

Berbeda halnya dengan kelas yang ajar dengan menggunakan model pembelajaran konvensional. Mahasiswa yang diajar dengan model pembelajaran konvensional, dimana proses pembelajaran lebih didominasi oleh dosen, sehingga mahasiswa yang memiliki motivasi belajar rendah akan semakin tidak memiliki kemauan yang kuat untuk mengikuti proses pembelajaran. Mereka akan cepat merasa bosan, sulit memahami pelajaran dan malas untuk bertanya kepada dosen. Meskipun sama-sama memiliki motivasi belajar rendah antara kelas eksperimen dengan kelas kontrol, tetapi terdapat perbedaan hasil belajar pada masingmasing kelas tersebut. Hal ini dikarenakan ada perbedaan perlakuan, yaitu pada kelas eksperimen diajar dengan menggunakan model pembelajaran kooperatif sedangkan pada kelas kontrol diajar dengan menggunakan model pembelajaran konvensional.

Interaksi Antara Model Pembelajaran Kooperatif Tipe Kancing Gemerincing dengan Motivasi Belajar Signifikan terhadap Hasil Belajar Mahasiswa pada Mata Kuliah Ekonomi Politik di Program Studi Pendidikan Ekonomi Fakultas Keguruan dan Ilmu Pendidikan Universitas Batanghari Jambi

Melihat interaksi antara model pembelajaran dan motivasi belajar bertujuan untuk mengetahui apakah 
Diliza Afrila, Pengaruh Model Pembelajaran Kooperatif Tipe Kancing Gemerincing dan Motivasi Belajar terhadap Hasil Belajar Mahasiswa pada Mata Kuliah Ekonomi Politik di Program Studi Pendidikan Ekonomi Fakultas Keguruan dan Ilmu Pendidikan Universitas Batanghari Jambi

terdapat hubungan yang saling mempengaruhi antara kedua variabel tersebut. Dari data dapat diketahui bahwa tidak terdapat interaksi antara model pembelajaran dan motivasi belajar terhadap hasil belajar. Di bawah ini dapat dilihat rata-rata hasil belajar mahasiswa berdasarkan model pembelajaran dan motivasi belajar.

Tabel 12. Rata-rata Hasil Belajar Mahasiswa Berdasarkan Model Pembelajaran dan Motivasi Belajar

\begin{tabular}{llccc}
\hline Model Motivasi & $\begin{array}{c}\text { Model Pembelajaran } \\
\text { Kancing Gemerincing }\end{array}$ & $\begin{array}{c}\text { Model Pembelajaran } \\
\text { Konvensional }\end{array}$ & $\begin{array}{c}\text { Rata- } \\
\text { rata }\end{array}$ \\
\hline Motivasi & Tinggi & 92,00 & 81,33 & $\mathbf{8 6 , 6 7}$ \\
& Rendah & 74,00 & 70,67 & $\mathbf{7 2 , 3 3}$ \\
Rata-rata & $\mathbf{8 3 , 0 0}$ & $\mathbf{7 6 , 0 0}$ & \\
\hline
\end{tabular}

Berdasarkan tabel 12 di atas dapat dilihat bahwa hasil belajar mahasiswa yang memiliki motivasi belajar tinggi yang diajar dengan model pembelajaran kooperatif tipe Kancing Gemerincing lebih tinggi daripada diajar dengan model pembelajaran konvensional, yaitu 92,00 > 81,33. Begitu juga dengan hasil belajar mahasiswa yang memiliki motivasi belajar rendah yang diajar dengan model pembelajaran kooperatif tipe Kancing Gemerincing lebih tinggi daripada diajar dengan model pembelajaran konvensional, yaitu 74,00 > 70,67. Mahasiswa yang memiliki motivasi belajar tinggi dan rendah di kelas eksperimen berjumlah 4 orang. Sedangkan, pada kelas kontrol berjumlah 3 orang. Apabila dilihat rata-rata hasil belajar mahasiswa yang memiliki motivasi belajar tinggi di kelas eksperimen dan kelas kontrol lebih tinggi dibanding rata-rata hasil belajar mahasiswa yang memiliki motivasi belajar rendah di kelas eksperimen maupun kelas kontrol.

Berdasarkan hasil penelitian menunjukkan bahwa motivasi belajar yang tinggi memperoleh hasil belajar yang tinggi pula, dan motivasi belajar rendah akan memperoleh hasil belajar yang rendah pula. Hal ini sesuai dengan pendapat Sanjaya (2008) yang mengatakan bahwa "Siswa yang memiliki motivasi belajar yang tinggi cenderung prestasinya akan tinggi. Sebaliknya, siswa yang memiliki motivasi belajar yang rendah cenderung prestasinya akan rendah". Artinya, tinggi atau rendahnya motivasi belajar yang dimiliki oleh mahasiswa akan menentukan hasil belajar yang dicapainya.

Berdasarkan hasil analisis hipotesis menunjukkan bahwa tidak terdapat interaksi antara model pembelajaran dan motivasi belajar terhadap hasil belajar mata kuliah Ekonomi Politik. Hal ini menunjukkan bahwa baik secara sendiri-sendiri atau secara bersama motivasi belajar dan hasil belajar mahasiswa yang mengikuti proses pembelajaran melalui model pembelajaran kooperatif tipe Kancing Gemerincing lebih baik daripada yang mengikuti proses pembelajaran melalui model pembelajaran konvensional. Hal ini sejalan dengan pendapat Sutikno (2009) yang mengemukakan bahwa hasil belajar seseorang ditentukan oleh berbagai faktor, salah satunya faktor yang ada di luar mahasiswa, yaitu dosen. Dosen yang mampu mengelola pembelajaran dengan metode-metode yang tepat dapat memberikan kemudahan bagi mahasiswa untuk mempelajari materi pelajaran sehingga menghasilkan hasil belajar yang lebih baik. Dapat disimpulkan bahwa hasil belajar mahasiswa yang memiliki motivasi belajar tinggi lebih tinggi dibanding hasil belajar mahasiswa yang memiliki motivasi belajar rendah. Namun demikian, model pembelajaran kooperatif tipe Kancing Gemerincing mampu meningkatkan hasil belajar mahasiswa baik itu yang memiliki motivasi belajar tinggi maupun motivasi belajar yang rendah sekalipun. Sehingga, tidak terdapat interaksi antara model pembelajaran dan motivasi belajar dalam mempengaruhi hasil belajar.

\section{SIMPULAN}

Berdasarkan pembahasan yang telah dikemukakan maka dapat diambil kesimpulan sebagai berikut:

1. Hasil belajar mahasiswa pada mata kuliah Ekonomi Politik yang diajar dengan menggunakan model pembelajaran kooperatif tipe Kancing Gemerincing lebih tinggi dari pada mahasiswa yang diajar dengan menggunakan model pembelajaran konvensional. Hal ini ditunjukkan oleh nilai thitung 2,159 dan nilai probabilitas 0,041 . Sehingga nilai probabilitas 0,041 $<0,05$ maka $\mathrm{H}_{0}$ ditolak.

2. Hasil belajar mahasiswa pada mata kuliah Ekonomi Politik yang memiliki motivasi belajar tinggi yang diajar dengan menggunakan model pembelajaran kooperatif tipe Kancing Gemerincing lebih tinggi dari pada mahasiswa yang memiliki motivasi belajar tinggi yang diajar dengan model pembelajaran konvensional. Hal ini ditunjukkan oleh nilai thitung 7,260 dan nilai probabilitas 0,001 . Sehingga, nilai probabilitas $0,001<0,05$ maka $\mathrm{H}_{0}$ ditolak.

3. Hasil belajar mahasiswa pada mata kuliah Ekonomi Politik yang memiliki motivasi belajar rendah yang diajar dengan menggunakan model pembelajaran kooperatif tipe Kancing Gemerincing lebih tinggi dari pada mahasiswa yang memiliki motivasi belajar rendah yang diajar dengan model pembelajaran konvensional. Hal ini ditunjukkan oleh nilai thitung 1,532 dan nilai probabilitas 0,006 . Sehingga, nilai probabilitas $0,006<0,05$ maka $\mathrm{H}_{0}$ ditolak.

4. Tidak terdapat interaksi antara model pembelajaran kooperatif tipe Kancing Gemerincing dan motivasi belajar terhadap hasil belajar mahasiswa pada mata kuliah Ekonomi Politik. Hal ini ditunjukkan oleh level Sig 0,205. Artinya, nilai Sig lebih besar dari nilai $\alpha=0,05(\operatorname{sig} \alpha)$ maka hipotesis nol $\left(\mathrm{H}_{0}\right)$ diterima. 
Diliza Afrila, Pengaruh Model Pembelajaran Kooperatif Tipe Kancing Gemerincing dan Motivasi Belajar terhadap Hasil Belajar Mahasiswa pada Mata Kuliah Ekonomi Politik di Program Studi Pendidikan Ekonomi Fakultas Keguruan dan Ilmu Pendidikan Universitas Batanghari Jambi

\section{DAFTAR PUSTAKA}

Boekaerts, Monique. 2002. Motivation to Learn. Geneva: International Bureu of Education.

Glynn, Shawn M; Aultman, Lori Price; Owens, Ashley M. 2005. "Motivation to Learn in General Education Program". The Journal of General Education, 54 (2): 150 - 170.

Kiswoyowati, Amin. 2011. "Pengaruh Motivasi dan Kegiatan Belajar Siswa terhadap Kecakapan Hidup Siswa". Edisi Khusus, (1): 120 - 126.

Peraturan Pemerintah No. 19 Tahun 2005 tentang Standar Nasional Pendidikan

Sanjaya, Wina. 2008. Strategi Pembelajaran Berorientasi Standar Proses Pendidikan. Jakarta: Kencana.

Sucipta, I Komang, I Gusti Ngurah Japa, dan I Gede Margunayasa. 2018. "Pengaruh Model Pembelajaran Kancing Gemerincing Terhadap Hasil Belajar IPA Kelas V'. Jurnal Mimbar Ilmu, (23) (3).

Sutikno, Sobry. 2009. Belajar dan Pembelajaran. Bandung: Prospect.

Trianto. 2010. Model Pembelajaran Terpadu, Konsep, Strategi dan Implementasinya dalam KTSP. Jakarta: Bumi Aksara. 